\title{
Conditions Determining Quality in Higher Education: Factors Affecting Satisfaction Levels of Prospective Teachers
}

\author{
Zeliha Nurdan Baysal, Kamil Ersin Araç* \\ Department of Primary, Marmara University, İstanbul, Turkey
}

Copyright@2019 by authors, all rights reserved. Authors agree that this article remains permanently open access under the terms of the Creative Commons Attribution License 4.0 International License

\begin{abstract}
This research aims to examine the elementary school teachers' levels of satisfaction in terms of their main field of study based on some demographic variables under such sub-dimensions as teaching staff, counseling, management, resources, computer facilities, courses and curriculum. Quantitative screening method was used in the research. The study group consists of 136 senior prospective primary school teachers from a state university. The data of this study was collected through the "Faculty of Education - Student Satisfaction Scale" developed by Şahin (2009) and the "Personal Information Form" prepared by the researchers. The collected data was analyzed by using the SPSS 18.0 package program, and percentage, frequency and arithmetic mean were calculated with descriptive statistical analysis methods. Mann Whitney U Test was used for the variable of gender, and Kruskal Wallis H Test was used for the variables of type of high school of graduation and academic success average. As a result, it was concluded that satisfaction levels of prospective teachers do not vary significantly by their genders and type of high school they graduated but vary by academic grade-point average. It was also found out that the sub-dimension on which the prospective teachers commented most positively was "consultancy services" while the dimension which they commented most negatively was "computer facilities." These findings were discussed within the framework of related literature and similar studies and various suggestions were brought forward.
\end{abstract}

Keywords Education, Primary Education, Teacher Training, Quality in Higher Education

\section{Introduction}

In the simplest manner of expression, education is qualified as the permanent change of behaviors of an individual. The notion of "education" consists of three main elements -namely student, teacher and program- that are continuously in interaction with each other. The efficiency and productivity of an educational system is dependent on these three elements working in harmony towards a particular goal. Each of these elements is very important. However, the element of "teacher" requires a careful concern, because faculties of education as institutions that train teachers do not have any control power on students, who are the inputs of the education system. The element of "program" is determined by the Ministry of National Education in Turkey. It has the most control power on the element of "teacher training" process for ensuring effective functioning of our education system. Teachers are the most effective on the two other elements (Karagözoğlu, Arıcı, Bülbül \& Çoker [1]). In the light of this information, while all elements of the system are important, the effect of the teacher particularly attracts attention.

The main purpose of the education system is to train qualified human resources of the country and provide citizenship education to its citizens. To accomplish this purpose, each education system determines the human model it will train in the light of its educational philosophy and human resources policy, and arranges its educational activities according to this purpose (Karagözoğlu [2]). Teachers play the leading role in carrying out these activities, and the quality of teachers is the most important factor that directly affects the quality of education (Aydin, Şahin \& Topal [3]). As stated by Kaya [4], training teachers with required qualities will ensure a country's development, because teachers are one of the most important elements for the development of a country. It has been revealed with several studies that teachers are one of the most important powers to change and develop the society's structure in the desired direction (Aydın [5]), and that teachers have an important role in the development of 
societies (Alkan and Kavcar [6]). In addition, the quality of the teacher is definitely related to the quality of the individual to be trained.

Training of primary school teachers have a special importance among teacher training systems, because the first years of primary education constitute the basis of the child's adult life, and the knowledge and skills acquired in this period have infrastructural characteristics for higher levels of education (Gürkan [7]). Primary school teachers assume important responsibilities in supporting cognitive development of children that come from their family environment, drawing a frame for and shaping their attitude towards themselves, the society and the outside world, and developing their communication, study and creative skills. Naturally, primary school teachers should also be subject to an effective pre-service and in-service training process in order to carry out their duties in the best way (Senemoğlu [8]). At this point, the importance and quality of education provided by universities that train the teacher are brought to the agenda.

Universities that train primary school teachers contribute to educational and scientific life as well as to the development of societies in all fields including economic, social and cultural fields. Moreover, universities are institutions that aim at student-centered education suitable for global development, raise enterprising and creative human resources and develop educational programs accordingly (Sakınç and Aybarç Bursalıoğlu [9]). Universities continuously require evaluation and improvement of quality.

Quality assessment in universities is traditionally identified with the evaluation of the teaching process and research. In evaluations at universities, individuals in the university (teaching staff, students and other personnel), main units (departments, units, centers) and processes within these units (instruction, research, management etc.) should be taken into consideration (Rebolloso and Pozo-Mun [10]). Evaluation of teachers in line with the students' opinions is one of the commonly used methods for determining the quality of instruction. In many countries, information obtained from these evaluations is used for constructive reforms.

A great importance is placed on the training of teachers in the education policies of countries in general, and especially in the European Union countries and it is subject to continuous reforms according to changing technological, political, economic and philosophical thought systems, trying always to create a better education system. Similar studies are carried out in Turkey; however, several problems in teacher training system are still being discussed. Both abroad and in our country, teacher training has many problems, arising from the fact that the process is complex and under the influence of many variables. Undoubtedly, prospective teachers are directly affected by the teacher training process (Baştürk [11]). Although various researches with both academicians and prospective teachers (e.g. Ceylan and Demirkaya [12]) are encountered in the related literature, it is seen that studies on the satisfaction levels of primary school teaching department are limited.

This research places emphasis on the importance of education, as well as emphasizing that the main reason of problems today is the deficiencies in primary education. Researchers think that the most important problem in education is the failure to train qualified primary school teachers. In this respect, determining the extent of sufficiency of classroom teaching program in training teachers is important for increasing the quality of teachers trained and eliminating the deficiencies of the program.

\subsection{Objective}

The objective of this research is to reveal the satisfaction levels of prospective primary school teachers on the main field they receive training, according to several variables. The answers to these questions were sought in line with this main objective:

1. What are the satisfaction levels of prospective primary school teachers on the main field they receive training?

2. Do the satisfaction levels of prospective primary school teachers on the department they receive training change according to teaching staff, consultancy services, management, resources, computer facilities, courses and curriculum?

\section{Materials and Methods}

Information on the research model, population and sample, data collection tools and how the data are analyzed is given below.

\subsection{Research Model}

This research is a descriptive research using quantitative screening model. Screening models are research approaches aiming to describe a situation, which existed in the past or still exists, in the way it is. They try to describe the case, individual or object subject to research under its own conditions and as it is. They do not make an effort to change or influence it (Karasar [13]). By using a descriptive approach, this study analyzes whether the satisfaction levels of prospective teachers in faculties of education on their life quality and on the training they receive change according to some demographic variables. During the process, a rigorous approach required for conducting a scientific research was adopted, and an objective perspective was meticulously maintained.

\subsection{Population and Sample}

The population of the research consists of 145 prospective teachers in total in their final years, who were 
receiving education in the Primary School Teaching Department of a state university in Istanbul because it was easily accessible for the researchers- in 2016-2017 academic year, and the sample consists of 136 prospective teachers selected with convenience sampling method. The main objective of convenience sampling method, also known as accidental/incidental sampling, is to prevent loss of time, money and labor. The researcher focuses on a case study which is the most accessible and will achieve maximum savings (Cohen and Mannion; Ravid, quoted by Büyüköztürk, Kılıç-Çakmak, Akgün, Karadeniz \& Demirel [14]). Demographics of prospective teachers who participated in the research are given in Table 1.

Table 1. Demographics of prospective teachers who participated in the research

\begin{tabular}{|l|l|l|}
\hline Gender & f & $\mathbf{\%}$ \\
\hline Female & 105 & 77.2 \\
\hline Male & 31 & 22.8 \\
\hline Type of High School of Graduation & $\mathbf{f}$ & $\mathbf{\%}$ \\
\hline Anatolian Teacher High School & 14 & 10.3 \\
\hline Anatolian High School & 71 & 52.2 \\
\hline General High School & 45 & 33.1 \\
\hline Other & 6 & 4.4 \\
\hline Academic Success & $\mathbf{f}$ & $\mathbf{\%}$ \\
\hline Grade Average between 1.00-2.00 & 8 & 5.9 \\
\hline Grade Average between 2.00-3.00 & 75 & 55.1 \\
\hline Grade Average between 3.00-4.00 & 53 & 39.0 \\
\hline Total & $\mathbf{1 3 6}$ & $\mathbf{1 0 0 . 0}$ \\
\hline
\end{tabular}

When Table 1 was reviewed, it was seen that $77.2 \%$ of the prospective teachers who participated in the research were female and $22.8 \%$ were male. $10.3 \%$ of the prospective teachers graduated from Anatolian Teacher High Schools, 52.2\% from Anatolian High Schools, 33.1\% from general high schools and $4.4 \%$ from other high school types. $5.9 \%$ of the prospective teachers have a grade average between $1.00-2.00,55.1 \%$ between 2.00-3.00, and 39.0\% between 3.00-4.00.

\subsection{Data Collection Tools}

The "Personal Information Form" prepared by the researchers to learn the prospective teachers' genders, types of high school of graduation and academic success levels was used for collecting data. "Faculty of Education-Student Satisfaction Scale (EF-ÖMÖ)" developed by Şahin [15] to determine the satisfaction levels of prospective teachers was also used.

It is seen that the internal consistency coefficients (Cronbach Alpha) for the six sub-dimensions of the scale used range between 0.68 and 0.91 . When evaluated in general terms, it was seen that all items were placed in the original form with factor loads ranging between.35 and.88. It was accepted that the items had a sufficient level of load in each dimension, and that each dimension measured what it was expected to measure, also with high reliability (Şahin [15]).
Table 2. Internal Consistency Coefficients for Faculty of Education-Student Satisfaction Scale

\begin{tabular}{|l|l|}
\hline Dimensions & Alpha \\
\hline 1. Teaching Staff & 0.91 \\
2. Consultancy Services & 0.93 \\
3. Management & 0.85 \\
4. Resources & 0.83 \\
5. Computer Facilities & 0.89 \\
6. Courses and curriculum & 0.68 \\
\hline
\end{tabular}

\subsection{Analysis of Data}

For the analysis of data obtained from the research, arithmetic mean and standard deviation, which are descriptive statistics, were used to determine the participants' satisfaction levels, trying to find out whether the satisfaction levels of prospective teachers change according to their genders, types of high school of graduation and grade average with variance analysis. SPSS 18.0 program was used in the analysis of Service Quality in Faculty of Education - Faculty of Education-Student Satisfaction Scale (EF-ÖMÖ).

Data from "Service Quality in Faculty of Education Faculty of Education-Student Satisfaction Scale (EF-ÖMÖ)" applied to determine the satisfaction levels of prospective primary school teachers in their final years were found by calculating percentage, frequency and arithmetic mean, which are descriptive statistics analysis methods. The purpose of this calculation is to determine the satisfaction levels of participants. The mean range was calculated to translate the mean values into oral expression. In this calculation, mean range was found to be $5-1=4,4 / 5=0.80$. The mean values were translated into oral expression by adding the mean range to each grade in the grading scale, starting from the smallest grade. The expressions were as follows: 1.00-1.80 Not at All Satisfied, 1.81-2.60 Slightly Satisfied, 2.61-3.40 Moderately Satisfied, 3.41-4.20 Highly Satisfied and 4.21-5.00 Completely Satisfied.

Non-parametric statistical methods were used to determine whether the satisfaction levels of prospectiveteachers change according to independent variables. Within this scope, Mann Whitney U Test was used for the variable of gender, and Kruskal Wallis H Test was used for the variables of type of high school of graduation and academic success average.

\section{Conclusions}

Findings obtained in consequence of the analysis of research data were presented in two headings; namely, satisfaction levels of prospective primary school teachers regarding the main field they receive education, and status of change according to variables discussed, in the order of questions within the scope of the study. 


\subsection{Findings on Satisfaction Levels of Prospective Primary School Teachers Regarding the Main Field They Receive Education}

The mean and standard deviation values for the scale as a whole and for each sub-dimension (consultancy services, teaching staff, courses and curriculum, computer facilities, resources and management) are shown below. Then, distributions of scale items constituting each subdimension of the scale were presented in Table 3.

Table 3. Number of Samples, Arithmetic Mean, Standard Deviation and Standard Error Values for the Satisfaction Scale as A Whole and for Each Sub-dimension

\begin{tabular}{lllll}
\hline $\begin{array}{l}\text { Sub-dimensions of } \\
\text { Satisfaction Scale }\end{array}$ & $\mathrm{N}$ & $\mathrm{X}$ & $\mathrm{SS}$ & $\mathrm{Sh}_{\mathrm{x}}$ \\
\hline Consultancy Services & 136 & 3.65 & 1.07 & $\mathbf{0 . 0 9}$ \\
Teaching Staff & 136 & 2.98 & $\mathbf{0 . 6 6}$ & $\mathbf{0 . 0 5}$ \\
Courses and Curriculum & 136 & 2.84 & $\mathbf{0 . 8 1}$ & $\mathbf{0 . 0 7}$ \\
Computer Facilities & 136 & 2.14 & $\mathbf{0 . 8 2}$ & $\mathbf{0 . 0 7}$ \\
Resources & 136 & 2.24 & $\mathbf{0 . 7 1}$ & $\mathbf{0 . 0 6}$ \\
Management & 136 & 2.16 & $\mathbf{0 . 8 1}$ & $\mathbf{0 . 0 6}$ \\
\hline Total & 136 & 2.68 & $\mathbf{0 . 5 8}$ & $\mathbf{0 . 0 5}$ \\
\hline
\end{tabular}

When Table 3 is analyzed according to arithmetic means for the sub-dimensions, the sub-dimension that the prospective teachers express the most positive opinions was "consultancy services" ( $\overline{\mathrm{X}}=3.65)$, followed by "teaching staff" $(\overline{\mathrm{X}}=2.98)$ and "courses and curriculum" $(\bar{X}=2.84)$. It was seen that the sub-dimension that prospective teachers express the most negative opinions was "computer facilities" ( $\overline{\mathrm{X}}=2.14)$, followed by "management" ( $\overline{\mathrm{X}}=2.16)$ and "resources" $(\overline{\mathrm{X}}=2.24)$. Considering the average of prospective teachers' answers to the satisfaction survey as a whole $(\overline{\mathrm{X}}=2.68)$, it is seen that they are "moderately satisfied".

\subsection{Findings on Whether Satisfaction Scale Points of Prospective Teachers within the Scope of the Research Change According to Independent Variables}

This section of the research covers statistical analysis findings to determine whether the satisfaction scale point averages of prospective teachers within the scope of the research as a whole or for each sub-dimension (consultancy services, training staff, courses and curriculum, computer facilities, resources and management) change according to independent variables (gender, academic success and type of high school of graduation).

When Table 4 is analyzed, looking at the results of Mann Whitney "U" (corrected with Bonferroni) performed to see whether the satisfaction scale point averages of prospective teachers change (with all sub-dimensions). It was found that satisfaction levels of prospective teachers do not show a statistically significant difference according to their gender (as a whole and for any of the sub-dimensions) $(\mathrm{P}>, 05)$. In line with this finding, satisfaction levels of prospective teachers that participated in the research do not change according to their gender.

Table 4. Results of Mann Whitney "U" Performed to Determine Whether the Satisfaction Scale Points of the Sample Group (as a Whole and with All Sub-dimensions) Change According to "Gender" Variable

\begin{tabular}{|c|c|c|c|c|c|c|c|}
\hline & Gender & $N$ & $\sum_{\text {sira }}$ & $\bar{X}_{\text {sira }}$ & $U$ & $Z$ & $p$ \\
\hline \multirow{3}{*}{ Consultancy Services } & Female & 105 & 71.06 & 7461.00 & \multirow{3}{*}{1359.000} & \multirow{3}{*}{-1.400} & \multirow{3}{*}{.161} \\
\hline & Male & 31 & 59.84 & 1855.00 & & & \\
\hline & Total & 136 & & & & & \\
\hline \multirow{3}{*}{ Teaching Staff } & Female & 105 & 68.95 & 7240.00 & \multirow{3}{*}{1580.000} & \multirow{3}{*}{-.247} & \multirow{3}{*}{.805} \\
\hline & Male & 31 & 66.97 & 2076.00 & & & \\
\hline & Total & 136 & & & & & \\
\hline \multirow{3}{*}{ Courses and Curriculum } & Female & 105 & 71.29 & 7485.50 & \multirow{3}{*}{1334.500} & \multirow{3}{*}{-1.526} & \multirow{3}{*}{.127} \\
\hline & Male & 31 & 59.05 & 1830.50 & & & \\
\hline & Total & 136 & & & & & \\
\hline \multirow{3}{*}{ Computer Facilities } & Female & 105 & 68.93 & 7238.00 & \multirow{3}{*}{1582.000} & \multirow{3}{*}{-.237} & \multirow{3}{*}{.813} \\
\hline & Male & 31 & 67.03 & 2078.00 & & & \\
\hline & Total & 136 & & & & & \\
\hline \multirow{3}{*}{ Resources } & Female & 105 & 69.13 & 7258.50 & \multirow{3}{*}{1561.500} & \multirow{3}{*}{-.342} & \multirow{3}{*}{.732} \\
\hline & Male & 31 & 66.37 & 2057.50 & & & \\
\hline & Total & 136 & & & & & \\
\hline \multirow{3}{*}{ Management } & Female & 105 & 69.31 & 7277.50 & \multirow{3}{*}{1542.500} & \multirow{3}{*}{-.441} & \multirow{3}{*}{.659} \\
\hline & Male & 31 & 65.76 & 2038.50 & & & \\
\hline & Total & 136 & & & & & \\
\hline \multirow{3}{*}{ Total } & Female & 105 & 70.90 & 7444.00 & \multirow{3}{*}{1376.000} & \multirow{3}{*}{-1.305} & \multirow{3}{*}{.192} \\
\hline & Male & 31 & 60.39 & 1872.00 & & & \\
\hline & Total & 136 & & & & & \\
\hline
\end{tabular}


According to the results of Kruskal Wallis-H Test performed to determine whether the satisfaction scale points of the prospective teachers that participated in the research (as a whole and with all subdimensions) change according to "type of high school of graduation" variable, the differences between groups' ranking average was not found statistically significant $(\mathrm{P}>, 05)$. In line with this finding, satisfaction levels of prospective teachers that participated in the research do not change according to the type of high school they graduated.

As per Table 6, according to the results of Kruskal Wallis-H Test performed to determine whether the satisfaction scale points of the prospective teachers that participated in the research (as a whole and with all sub-dimensions) change according to "academic grade average" variable, the differences between groups' ranking average was not found statistically significant $(\mathrm{P}>, 05)$. However, point averages for training staff sub-dimension of the prospective teachers satisfaction scale was seen to change significantly according to academic grade averages $(\mathrm{P}<, 05)$. Accordingly, when the points for teaching staff sub-dimension were analyzed, it was found out that the satisfaction from teaching staff increases together with the increase in grade average.

Table 5. Results of Kruskal Wallis-H Test Performed to Determine Whether the Satisfaction Scale Points of the Sample Group (as a Whole and with All Sub-dimensions) Change According to "Type of High School of Graduation" Variable

\begin{tabular}{|c|c|c|c|c|c|c|}
\hline & Type of High School & $N$ & $\bar{X}_{\text {sira }}$ & $x^{2}$ & sd & $p$ \\
\hline \multirow{5}{*}{$\begin{array}{l}\text { Consultancy } \\
\text { Services }\end{array}$} & Anatolian Teacher High School & 14 & 64.86 & \multirow{5}{*}{2.833} & \multirow{5}{*}{3} & \multirow{5}{*}{.418} \\
\hline & Anatolian High School & 71 & 64.57 & & & \\
\hline & General High School & 45 & 76.53 & & & \\
\hline & Other & 6 & 63.25 & & & \\
\hline & Total & 136 & & & & \\
\hline \multirow{5}{*}{ Teaching Staff } & Anatolian Teacher High School & 14 & 74.75 & \multirow{5}{*}{7.433} & \multirow{5}{*}{3} & \multirow{5}{*}{.059} \\
\hline & Anatolian High School & 71 & 60.23 & & & \\
\hline & General High School & 45 & 80.08 & & & \\
\hline & Other & 6 & 65.00 & & & \\
\hline & Total & 136 & & & & \\
\hline \multirow{5}{*}{$\begin{array}{l}\text { Courses and } \\
\text { Curriculum }\end{array}$} & Anatolian Teacher High School & 14 & 56.61 & \multirow{5}{*}{5.075} & \multirow{5}{*}{3} & \multirow{5}{*}{.166} \\
\hline & Anatolian High School & 71 & 65.96 & & & \\
\hline & General High School & 45 & 78.11 & & & \\
\hline & Other & 6 & 54.25 & & & \\
\hline & Total & 136 & & & & \\
\hline \multirow{5}{*}{$\begin{array}{l}\text { Computer } \\
\text { Facilities }\end{array}$} & Anatolian Teacher High School & 14 & 78.18 & \multirow{5}{*}{3.047} & \multirow{5}{*}{3} & \multirow{5}{*}{.384} \\
\hline & Anatolian High School & 71 & 63.58 & & & \\
\hline & General High School & 45 & 71.26 & & & \\
\hline & Other & 6 & 83.42 & & & \\
\hline & Total & 136 & & & & \\
\hline \multirow{5}{*}{ Resources } & Anatolian Teacher High School & 14 & 62.61 & \multirow{5}{*}{4.307} & \multirow{5}{*}{3} & \multirow{5}{*}{.230} \\
\hline & Anatolian High School & 71 & 63.90 & & & \\
\hline & General High School & 45 & 78.44 & & & \\
\hline & Other & 6 & 62.08 & & & \\
\hline & Total & 136 & & & & \\
\hline \multirow{5}{*}{ Management } & Anatolian Teacher High School & 14 & 59.89 & \multirow{5}{*}{4.362} & \multirow{5}{*}{3} & \multirow{5}{*}{.225} \\
\hline & Anatolian High School & 71 & 64.06 & & & \\
\hline & General High School & 45 & 78.30 & & & \\
\hline & Other & 6 & 67.67 & & & \\
\hline & Total & 136 & & & & \\
\hline \multirow{5}{*}{ Total } & Anatolian Teacher High School & 14 & 66.21 & \multirow{5}{*}{7.290} & \multirow{5}{*}{3} & \multirow{5}{*}{.063} \\
\hline & Anatolian High School & 71 & 61.14 & & & \\
\hline & General High School & 45 & 81.27 & & & \\
\hline & Other & 6 & 65.17 & & & \\
\hline & Total & 136 & & & & \\
\hline
\end{tabular}


Table 6. Results of Kruskal Wallis-H Test Performed to Determine Whether the Satisfaction Scale Points of the Sample Group (as a Whole and with All Sub-dimensions) Change According to "Academic Grade Average" Variable

\begin{tabular}{|c|c|c|c|c|c|c|}
\hline Point & Grade Average & $N$ & $\bar{X}_{\text {sira }}$ & $x^{2}$ & $s d$ & $p$ \\
\hline \multirow{4}{*}{ Consultancy Services } & Between 1.00-2.00 & 8 & 49.25 & \multirow{4}{*}{2.124} & \multirow{4}{*}{2} & \multirow{4}{*}{.346} \\
\hline & Between 2.00-3.00 & 75 & 68.91 & & & \\
\hline & Between 3.00-4.00 & 53 & 70.82 & & & \\
\hline & Total & 136 & & & & \\
\hline \multirow{4}{*}{ Teaching Staff } & Between 1.00-2.00 & 8 & 35.31 & \multirow{4}{*}{8.099} & \multirow{4}{*}{2} & \multirow{4}{*}{$.017^{*}$} \\
\hline & Between 2.00-3.00 & 75 & 64.77 & & & \\
\hline & Between 3.00-4.00 & 53 & 74.64 & & & \\
\hline & Total & 136 & & & & \\
\hline \multirow{4}{*}{$\begin{array}{l}\text { Courses and } \\
\text { Curriculum }\end{array}$} & Between 1.00-2.00 & 8 & 67.81 & \multirow{4}{*}{1.485} & \multirow{4}{*}{2} & \multirow{4}{*}{.476} \\
\hline & Between 2.00-3.00 & 75 & 64.99 & & & \\
\hline & Between 3.00-4.00 & 53 & 73.57 & & & \\
\hline & Total & 136 & & & & \\
\hline \multirow{4}{*}{ Computer Facilities } & Between 1.00-2.00 & 8 & 68.19 & \multirow{4}{*}{.677} & \multirow{4}{*}{2} & \multirow{4}{*}{.713} \\
\hline & Between 2.00-3.00 & 75 & 70.92 & & & \\
\hline & Between 3.00-4.00 & 53 & 65.12 & & & \\
\hline & Total & 136 & & & & \\
\hline \multirow{4}{*}{ Resources } & Between 1.00-2.00 & 8 & 67.13 & \multirow{4}{*}{.545} & \multirow{4}{*}{2} & \multirow{4}{*}{.761} \\
\hline & Between 2.00-3.00 & 75 & 70.73 & & & \\
\hline & Between 3.00-4.00 & 53 & 65.56 & & & \\
\hline & Total & 136 & & & & \\
\hline \multirow{4}{*}{ Management } & Between 1.00-2.00 & 8 & 83.19 & \multirow{4}{*}{2.897} & \multirow{4}{*}{2} & \multirow{4}{*}{.235} \\
\hline & Between 2.00-3.00 & 75 & 71.41 & & & \\
\hline & Between 3.00-4.00 & 53 & 62.16 & & & \\
\hline & Total & 136 & & & & \\
\hline \multirow{4}{*}{ Total } & Between 1.00-2.00 & 8 & 66.88 & \multirow{4}{*}{.107} & \multirow{4}{*}{2} & \multirow{4}{*}{.978} \\
\hline & Between 2.00-3.00 & 75 & 69.49 & & & \\
\hline & Between 3.00-4.00 & 53 & 67.34 & & & \\
\hline & Total & 136 & & & & \\
\hline
\end{tabular}

\section{Result, Discussion and Recommendations}

According to the findings obtained, the results of this research are presented in two headings.

\subsection{Results on Satisfaction Levels of Prospective Primary School Teachers Regarding the Main Field They Receive Education}

- The satisfaction of prospective primary school teachers regarding the main field they receive education is "moderate". It was concluded that the sub-dimension that prospective teachers are the most satisfied is "consultancy services", while the sub-dimension that they are the least satisfied is "computer facilities". Satisfaction levels are; consultancy services, training staff, courses-curriculum, resources, management and computer facilities respectively.

Moreover, this result can also be interpreted that the expectations of prospective teachers towards the faculty life are not exactly met. When the literature is reviewed, student satisfaction differs in various studies on the issue.

Şahin [15] concluded that student satisfaction was ensured at "moderate" level in the sub-dimensions of training staff, consultancy services and curriculum; while it was at "very low" level in the subdimensions of management, resources and computer facilities. In this sense, the satisfaction levels for the two studies in sub-dimensions show similarities. Donat-Bacioğlu and Vural [16] concluded that the satisfaction levels of prospective teachers receiving training in Trakya University Faculty of Education regarding the university and faculty was "moderate", while Akdoğdu and Uşun 
[17] also concluded that prospective primary school teachers evaluated the program as moderately sufficient. Similarly, Ceylan and Demirkaya [12] noted that prospective primary school teachers in their fourth year were moderately satisfied for each dimension of services provided by their universities and faculties. The present study is shows similarities with these studies. Özdemir, Kılınç, Öğdem \& Er [18] concluded that the satisfaction of students in the faculty of education on the quality of faculty life was at moderate level.

Aksu [19] noted that students receiving training in Giresun University were generally satisfied from their university/department. However, Özçakır-Sümen and Çağlayan [20] concluded in their studies that prospective teachers were generally "slightly" satisfied from the faculty of education. Erdoğan, Şanlı \& Şimşek-Bekir [21] also concluded that students in Gazi University Faculty of Education found the university/faculty below their expectations and were not satisfied at all.

\subsection{Results on the Change of Satisfaction Levels of Prospective Primary School Teachers Regarding the Main Field They Receive Education According to Gender, Type of High School of Graduation and Academic Grade Average}

- Satisfaction levels of prospective primary school teachers regarding the main field they receive education do not show a statistically significant change according to gender in any of the subdimensions.

It can be thought that the lack of significant changes in the satisfaction levels of prospective teachers on the quality of faculty life according to the variable of gender is related to the fact that they share a similar environment and encounter with the same practices. Studies that reach both similar and different conclusions can be seen in literature. It is found that there are similar (Bacioğlu and Vural, 2018; Akdoğdu and Uşun, 2017; Yavuz and Gülmez, 2016; Özdemir, Kılınç, Öğdem and Er, 2013; Bilgiç and Sarı, 2010) and different result of some studies (Ada, Baysal and Şahenk-Erkan, 2017; Beaumont, 2012; Özdemir, 2012; Çokluk-Bökeoğlu and Yılmaz, 2007) in the field of literature.

- Satisfaction levels of prospective primary school teachers regarding the main field they receive education do not show a statistically significant change according to the type of high school of graduation in any of the sub-dimensions.

Considering that all prospective teachers may be affected by the lack of opportunities or some facilities offered in their main field, regardless of the type of high school they graduated, this finding obtained from the research is in line with the expectations. Similar to the present study, it was seen in the findings of Sert [28] that there is no significant difference between the satisfaction levels of students receiving undergraduate education on tourism and the type of high school they graduated from.

- Satisfaction levels of prospective primary school teachers regarding the main field they receive education do not show a statistically significant change according to the variable of academic grade average in any of the sub-dimensions. However, point averages for training staff sub-dimension of the prospective teachers satisfaction scale was seen to change significantly according to academic grade averages. Accordingly, when the points for teaching staff sub-dimension were analyzed, it was found out that the satisfaction from teaching staff increases together with the increase in grade average.

It was found out in the present study that academic success is not related to being satisfied with the education program. Similar to the present study, it was found in the study by Donat-Bacioğlu and Vural [16] that the opinions of students in faculty of education on academic services do not differ significantly according to academic grade average. Sert [28] also obtained similar results, although Ada, Baysal and Şahenk-Erkan [24] found out significant differences in the prospective teachers' perception of service quality in higher education according to their success levels in all subfactors. Similarly Yıldırım, Demirtaş-Zorbaz, Ulaş, Kızıldağ \& Dinçel [29] found out that students with high academic success were satisfied with the program they received education. Within the scope of international studies by Farahmandian, Minavand \& Afshardost [30] and Beaumont [25], the perception of service quality in higher education showed significant differences according to the student's success levels in many sub-factors. In their study; Yelkikalan, Sümer \& Temel [31] also found significant differences between the success levels of students and their perception of servicequality in higher education in some sub-factors of higher education institutions. The findings of Yaşar and Balkıs [32] also do not correspond to the findings of the present study.

Based on these results, the following recommendations can be given:

- One of the most important objectives of universities' undergraduate programs should be improving perception of service quality in higher education.

- Developments of maximum level may be recommended to improve the current conditions in universities. The precautions may be increased according to the satisfaction areas of male students, especially in terms of academic direction and educational image.

- $\quad$ Based on the satisfaction level results of studies in Turkish literature and of the present study, it is synthesized that results on gender, type of high school of graduation and academic success show 
differences. Therefore, it may be recommended to carry out new studies on how satisfaction levels interact with various variables.

- Reasons that affect the perceptions of prospective teachers on teaching staff, consultancy services, management, resources, computer facilities and courses-curriculum in private universities and state universities may be analyzed by comparison and by using different research methods.

- The researchers are recommended to analyze the satisfaction levels of prospective teachers that receive training in other departments of the faculties of education.

- $\quad$ Research can be done with larger samples, including other grade levels.

\section{REFERENCES}

[1] Karagözoğlu, G., Arıcı H., Bülbül S., Çoker N. (1993). Türkiye'de Öğretmen Eğitim Politikaları ve Modelleri. Avrupa Konseyi Ülkeleri Öğretmen Yetiştirme Politikaları ve Modelleri Toplantısı. Ankara: Milli Eğitim Basımevi.

[2] Karagözoğlu, G. (2003). Eğitim Sistemimizde öğretmen yetiştirme politikamıza genel bir bakış, eğitimde yansımalar. VII Çağdaş Eğitim Sistemlerinde Öğretmen Yetiștirme Sempozyumu, Cumhuriyet Üniversitesi Kültür Merkezi.

[3] Aydın, R., Şahin, H. and Topal, T. (2008). Türkiye’de İlköğretime Sınıf Öğretmeni Yetiștirmede Nitelik Arayışları, TSA, Y11 12, say1 2.

[4] Kaya, Y. K. (1984). İnsan Yetiştirme Düzenimiz: Politika-Eğitim-Kalkınma (4. basım). Ankara: Hacettepe Üniversitesi Sosyal ve İdari Bilimler Döner Sermaye İşletmesi Tesisleri.

[5] Aydın, R. (2007), “Türkiye'de Eğitimle İlgili Yapılan Bilimsel Toplantılarda ve Millî Eğitim Şûralarında Ele Alınan Öğretmen Sorunları ile Millî Eğitim Bakanlığı'nın Politika ve Uygulamalarının Değerlendirilmesi (1980 2004)”. Ankara University Graduate School of Educational Sciences (Unpublished PhD Thesis). Ankara: 2008.

[6] Alkan C. and Kavcar C. (1998) "Bilgi Çağında Eğitimde Öğretmenlik Mesleğinin Yeniden Yapılanması", Sözlü Bildiri, Bilgi Çağında Öğretmenlik Sempozyumu, Anadolu Çağdaş Eğitim Vakfı (ANÇEV): Ankara.

[7] Gürkan, T. (1993). İlkokul Öğretmenlerinin Öğretmenlik Tutumları ile Benlik Kavramları Arasındaki İlişki. Ankara: Sevinç Matbaası.

[8] Senemoğlu, S. (1992). "İngiltere'de İlköğretime Öğretmen Yetiştirme ve Türkiye ile Karşılaştırılması - Türkiye'de İlköğretime Öğretmen Yetiştirmenin Geliştirilmesi İçin Bazı Öneriler”. Hacettepe Üniversitesi Eğitim Fakültesi Dergisi, 8, 143-156.

[9] Sakınç, S. and Aybarç Bursalıoğlu, S. (2012). Yükseköğretimde Küresel Bir Değişim: Girişimci Üniversite Modeli. Journal of Higher Education and Science, 2(2), 92-99.
[10] Rebolloso-Pacheco and Pozo-Muñ, C (2000). “The 'Ideal Teacher' Implications For Student Evaluation Of Teacher Effectiveness", Assessment \& Evaluation in Higher Education, 25, No. 3.

[11] Baştürk, S. (2011). Matematik öğretmen adaylarının eğitim fakültesindeki eğitim-öğretim sürecini değerlendirmeleri. International Journal of Human Sciences, 8(1), 58-94.

[12] Ceylan, S. and Demirkaya, H. (2006). Sınıf öğretmen adaylarının sınıf öğretmenliği programı ve program dâhilinde sunulan hizmetler konusundaki memnuniyet düzeyleri. Mehmet Akif Ersoy Üniversitesi Eğitim Fakültesi Dergisi, 7, 12, 146-160.

[13] Karasar, N. (2012). Bilimsel araștırma yöntemleri. Ankara: Nobel.

[14] Büyüköztürk, Ş., Kılıç Çakmak, E., Akgün, Ö.E., Karadeniz, Ş. and Demirel, F. (2017). Bilimsel araştırma yöntemleri (23. baskı). Ankara: Pegem Akademi Yayınları.

[15] Sahin, A. E. (2009). "Eğitim Fakültesinde Hizmet Kalitesinin Eğitim Fakültesi Öğrenci Memnuniyet Ölçeği(EF-ÖMÖ) İle Değerlendirilmesi," Hacettepe Üniversitesi Eğitim Fakültesi Dergisi, 37, 106-122.

[16] Donat-Bacığlu, S. and Vural, L. (2018). Öğretmen adaylarının akademik hizmetlere ilişkin görüşleri ve memnuniyet düzeyleri. Mehmet Akif Ersoy Üniversitesi Eğitim Fakültesi Dergisi, 47, 158-178 ISSN:1302-8944

[17] Akdoğdu, E. and Uşun, S. (2017). Sınıf öğretmenliği lisans programının öğretmen adaylarının görüşleri doğrultusunda bağlam, girdi, süreç ve ürün (CIPP) modeli ile değerlendirilmesi. İlköğretim Online/ Elementary Education Online, 16(2): 826-847. [Online]:http://ilkogretim-online.or g.tr doi: 10.17051/ilkonline.2017.304738

[18] Özdemir, S., Kılınç, A. Ç., Öğdem, Z. and Er, E. (2013). Eğitim Fakültesi Öğrencilerinin Fakülte Yaşamının Niteliğine İlişkin Memnuniyet Düzeylerinin Çeşitli Değişkenler Açısından İncelenmesi. Journal of Higher Education \& Science/Yüksekögretim ve Bilim Dergisi, 3(3), 228-235.

[19] Aksu, H. H. (2016). Eğitim fakültesinde öğrenim gören öğrencilerin bölümleri hakkındaki görüşleri: Giresun Üniversitesi örneği. Kastamonu Eğitim Dergisi, 24(1), 299-316.

[20] Özçakır-Sümen, Ö. and Çağlayan, K. T. (2013) Öğretmen adaylarının eğitim fakültesinden memnuniyet düzeyleri ve hayal ettikleri eğitim ortamı. Ondokuz Mayıs Üniversitesi Eğitim Fakültesi Dergisi, 32(2), 249-272. ISSN: 1300-302X (C) 2013 OMÜ EĞİTIM FAKÜLTESİ

[21] Erdoğan, S., Şanlı, S. and Şimşek-Bekir, H. (2005). Gazi üniversitesi, eğitim fakültesi öğrencilerinin üniversite yaşamına uyum durumları. Kastamonu Eğitim Dergisi, 13(2), 479-496.

[22] Yavuz, M. and Gülmez, D. (2016). The Assessment of Service Quality Perception in Higher Education, Education and Science, 41(184), 251-265.

[23] Bilgiç, S., and Sarı, M. (2010). İlköğretim öğrencilerinin okul yaşam kalitesi ve empatik sınıf atmosferi algıları. Eğitim ve Uygulama, 9(17), 1-19.

[24] Ada, S., Baysal, Z. N. and Şahenk-Erkan, S. S. (2017). An 
evaluation of service quality in higher education: Marmara and Niğde Omer Halisdemir universities' department of education students. Universal Journal of Educational Research, 5(11), 2056-2065. http://www.hrpub.org DOI: 10.13189/ujer.2017.051122

[25] Beaumont, D. (2012). Service quality in higher education: the students' view point. BSc (Honors) in Management, USA: Manchester University Manchester Business School.

[26] Özdemir, M. (2012). Üniversite öğrencilerinin okul yaşamının niteliğine ilişkin algılarının cinsiyet ve fakülte değişkenlerine göre incelenmesi. Kuram ve Uygulamada Eğitim Yönetimi, 18(2), 225-242.

[27] Çokluk Bökeoğlu, Ö. and Yılmaz, K. (2007). Üniversite öğrencilerinin fakülte yaşamının niteliğine ilişkin görüşlerinin çeşitli değişkenler açısından incelenmesi. Ankara Üniversitesi Eğitim Bilimleri Fakültesi Dergisi, 40(2), 179-204.

[28] Sert, S. (2012). Lisans düzeyinde turizm eğitimi alan öğrencilerin memnuniyet düzeyleri ile not ortalamaları arasındaki ilişki. Turizm Eğitimi Konferansı, Ankara, 17-19.

[29] Yıldırım, İ., Demirtaş-Zorbaz, S., Ulaş, Ö., Kızıldağ, S. and Dinçel, E. (2017). Akademik başarısı düşük ve yüksek olan üniversite öğrencilerinin nitelikler. Kastamonu Eğitim Dergisi, 25(6), 2190-2214.

[30] Farahmandian, S., Minavand, H. and Afshardost, M. (2013). Perceived service quality and student satisfaction in higher education. IOSR Journal of Business and Management (IOSR-JBM), e-ISSN: 2278-487X, p-ISSN: 2319-7668, 12(4), 65-74.

[31] Yelkikalan, N., Sümer, B. and Temel, S. (2006) "Fakültelerin Değerlendirilmesinde Öğrenci Algılamaları Biga İktisadi ve İdari Bilimler Fakültesi Öğrencileri Üzerine Bir Araştırma", s. 144-160.

[32] Yaşar, M. and Balkıs, M. (2004). Pamukkale Üniversitesi Eğitim Fakültesi'nde Yaz Okuluna Kayıt Yaptıran Öğrencilerin Başarısızlık Nedenlerinin İncelenmesi. Pamukkale Üniversitesi Eğitim Fakültesi Dergisi, 15(1), 130-165. 